I N F ORM A T I K

Jurnal Informatika, Manajemen dan Komputer, Vol. 13, No. 2, Desember 2021

eISSN : 2580-3042

pISSN : 1979-0694

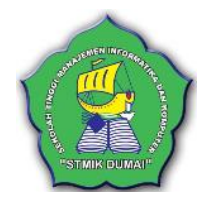

\title{
SISTEM PENDUKUNG KEPUTUSAN DALAM PENENTUAN JURUSAN SISWA SMK MENERAPKAN METODE SAW
}

\author{
Sri Wahyuni ${ }^{1}$, Haniarsih ${ }^{2}$ \\ ${ }^{1,2}$ Universitas Panca Sakti Bekasi \\ Jl. Kapten Sumantri No 16 Cikarang Bekasi \\ e-mail: sriyuni82.sw@ gmail.com, haniarsih17429065@gmail.com²
}

\begin{abstract}
ABSTRAK
SMK Islam Al Amin memiliki empat pilihan jurusan yang bisa dipilih calon siswa. Dengan peminatan tanpa adanya tes, maka terjadi penumpukan jumlah siswa di satu jurusan yaitu Teknik Komputer Jaringan (TKJ), kemudian dirubahlah cara penentuan jurusan yang dilaksanakan dengan tes atau penyaringan berdasarkan kemampuan. Dengan cara yang dilaksanakan sekarang, wakasek kurikulum kerepotan karena masih mengandalkan laporan dari hasil tes. Dalam penelitian ini dirumuskan sebuah aplikasi berbasis web dengan menerapkan metode Simple Additive Weighting (SAW) untuk membantu wakasek dalam penentuan jurusan siswa. Dan terbukti hasil implementasi dari aplikasi yang dibuat menunjukkan nilai positif yaitu dapat diterima dan digunakan sebagai penunjang keputusan penentuan jurusan siswa di SMK Islam Al Amin Bekasi.
\end{abstract}

Kata kunci: Sisem Penunjang Keputusan, SAW, Penjurusan.

\section{ABSTRACT}

SMK Islam Al Amin has four majors that prospective students can choose from. With specialization without a test, there is an accumulation of the number of students in one department, namely Computer Network Engineering (TKJ), then the method of determining the majors is changed by means of tests or screening based on ability. With the way it is being implemented now, the vice secretary of the curriculum is having problems because they still rely on reports from test results. In this study, a web-based application was formulated by applying the Simple Additive Weighting (SAW) method to help the vice principal in determining student majors. And it is proven that the results of the implementation of the application made show a positive value that can be accepted and used as a decision supporter for determining student majors at SMK Al Islam Amin Bekasi.

Key word: DSS, SAW, Majors, Decission Support System.

\section{PENDAHULUAN}

Sekolah Menengah Kejuruan (SMK) Islam AL Amin adalah salah satu sekolah SMK di Bekasi yang memiliki empat buah jurusan yaitu Teknik Komputer Jaringan (TKJ), Akuntansi Keuangan dan Lembaga (AKL), Otomatisasi dan Tata Kelola Perkantoran (OTKP) dan Bisnis Daring dan Pemasaran (BDP). Sistem pejurusan yang digunakan saat ini masih mengalami kendala karena hanya berdasarkan minat atau keinginan siswa, sehingga menimbulkan penumpukan hanya di salah satu jurusan yang mengakibatkan jurusan yang lainnya menjadi tidak ada peminatnya.
Wakasek memerlukan waktu lebih banyak dalam penentuan jurusan siswa. Hal ini dikarenakan siswa lebih cenderung memilih jurusan yang lebih banyak temannya saja. Siswa masih sedikit mengesampingkan kemampuannya dalam mata pelajaran utama dalam jurusan yang dia pilih.

Kemampuan dan minat siswa didapat dari sistem jalur undangan yang sejenis dengan Penelusuran Minat dan Kemampuan, dimana yang akan menjadi pertimbangan dalam penilaian penjurusan yaitu nilai test pada 5 (lima) mata pelajaran yang diujikan setelah masuk menjadi siswa kelas X. Kelima Mata Pelajaran tersebut adalah Matematika, Bahasa Inggris, Bahasa 
IN F O R M A I I A

Jurnal Informatika, Manajemen dan Komputer, Vol. 13, No. 2, Desember 2021

eISSN : 2580-3042

pISSN : 1979-0694

Indonesia, Ipa dan Tik. Dari kriteria inilah yang digunakan dalam proses perhitungan.

Maka, diperlukan sebuah sistem pendukung keputusan dalam penentuan jurusan agar menghasilkan keputusan yang mendekati objektif. Dalam penelitian ini menggunakan metode Simple Additive Weighting (SAW). Dalam penelitian ini menggunakan data sampel dari SMK Islam Al Amin Cikarang Bekasi.

Menurut (Kusrini, 2007) "Sistem merupakan kumpulan elemen yang saling berkaitan yang bertanggung jawab memproses masukan (input) sehingga menghasilkan keluaran (output).”.

Menurut Fishburn dan MacCrimmon dalam (Munthe, 2013) mengemukakan bahwa Metode Simple Additive Weight (SAW), sering juga dikenal dengan istilah metode penjumlahan terbobot. Konsep dasar metode Simple Additive Weight (SAW) adalah mencari penjumlahan terbobot dari rating kinerja pada setiap alternatif pada semua atribut. Menurut (Asnawati dan Kanedi, 2012) "Kriteria penilaian dapat ditentukan sendiri sesuai dengan kebutuhan perusahaan.

\section{METODOLOGI PENELITIAN}

Penulis melakukan penelitian di SMK ISLAM AL AMIN Cikarang Utara yang beralamat di Jl. Industri Km. 3 Blok T Pasirgombong Cikarang utara -Bekasi 17530. No. Telphon : 02189321208 metode pengumpulan data dalam penelitian ini meliputi:

a. Obervasi

Peneliti melakukan pengamatan langsung ke lokasi penelitian dengan mengamati proses penentuan jurusan siswa. Dari proses ini mendapatkan data alternatif dan kriteria.

\section{b. Wawancara}

Peneliti melaksanakan wawancara kepada Wasi Gunawan, S.Pd sebagai Wakil Kepala Sekolah bidang Kurikulum SMK Islam Al Amin pelaksana penentu penjurusan siswa pada hari Sabtu tanggal 8 Mei 2021 di SMK Islam $\mathrm{Al}$ Amin mendapatkan hasil berupa data pembobotan masing-masing kriteria dan proses penentuan jurusan siswa.

c. Studi Pustaka

Peneliti membaca jurnal penelitian yang menerapkan metode SAW untuk dapat mereferensi dan membandingkan hasil penelitian.

Penelitian pertama dilakukan oleh Rusdiansyah, Ikhsan Shahlin Mustofa yang berjudul "Analisis Keputusan Menentukan
Jurusan Pada Sekolah Menengah Kejuruan Dengan Metode Simple Additive Weighting". Dalam penelitian ini dikembangkan sistem pendukung keputusan menggunakan metode yang dapat menyelesaikan permasalahan Multiple Atrribute Decision Making (MADM) yang terbukti memiliki kinerja yang sangat efektif terhadap data-data yang nilainya berupa kisaran dalam jangkauan nilai tertentu. Metode SPK yang digunakan dalam penelitian adalah Simple Additive Weighting (SAW). Metode ini menentukan nilai bobot untuk setiap atribut, yang dilanjutkan dengan proses perangkingan. Sehingga akanmenghasilkan alternatif terbaik dari banyak alternatif dengan perhitungan yang cukup tepat.

Penelitian yang kedua dilakukan oleh Dian Novita Handayani, Fitro Nur Hakim, Achmad Solechan. Yang berjudul "Perancangan Sistem Pendukung Keputusan Pemilihan Jurusan Di Sma Berdasarkan Nilai Akadamik Dan Minta Siswa Menggunakan Fuzzy Simple Additive Weighting". penjurusan di SMA saat ini masih dilakukan dengan mamual dan memiliki kecenderungan melihat nilai akedemik siswa saja. Jika nilai siswa memenuhi standar KKM (Kriteria Keluntasan Minimum) yang telah ditentukan oleh sekolah maka dapat ditentukan siswa tersebut masuk salah satu jurusan yang ada. Sedangkan untuk melihat minat siswa, biasanya siswa diminta mengisi kuesioner secara manual. Cara manual tersebut menjadi kurang pruktis dan memakan waktu yang lama, rentan terjadi kesalahan dalam pemeriksaan dan penilaian sehingga kesalahan dapat terjadi dalam menentukan nilai. Kesulahun dalam memilih jurusan akan merugikan bagi siswa, baik dari biaya maupun waktu. Sistem pendukung keputusan pemilihan jurusan di SMA menggunakan metode Fucy Simple Additive Wighting (FSAW) dibangun untuk membantu sekolah dalam mempermudah menentukan jurusan. Kriteria yang digunakan odalah nilai akademik siswa dan minat siswa.

Penelitian yang ketiga Alfi Dwi Sukmawan. Yang berjudul "Sistem Pendukung Keputusan Pemilihan Jurusan Di Perguruan Tinggi". Dalam penerapan tes yang dilakukan masih menggunakan sistem manual sehingga dalam pengambilan keputusannya masih harus menunggu waktu yang cukup lama. Maka dibuatlah sistem penunjang keputusan untuk pemilihan jurusan di perguruan tinggi.

Penelitian keempat dilakukan oleh Frieyadie dengan judul Penerapan Metode 
I N F O R M A I I A

Jurnal Informatika, Manajemen dan Komputer, Vol. 13, No. 2, Desember 2021

eISSN : 2580-3042

pISSN : 1979-0694

Simple Additive Weight (Saw) Dalam Sistem Pendukung Keputusan Promosi Kenaikan Jabatan. Dalam penelitian ini menghasilkan sebuah aplikasi yang menerapkan metode SAW sebgai referensi pengambilan keputusan promosi kenaikan jabatan. Untuk mendapatkan promosi jabatan seorang karyawan tidak hanya dilihat dari segi seberapa lamanya karyawan tersebut bekerja tetapi juga harus memiliki kinerja dan perilaku yang baik.

Adapun langkah penyelesaian dalam menggunakan meode $S A W$ adalah:

1. Menentukan alternatif, yaitu $\mathrm{A}_{\mathrm{i}}$,

2. Menentukan kriteria yang akan dijadikan acuan dalam pengambilan keputusan, yaitu $\mathrm{C}_{\mathrm{j}}$

3. Menentukan bobot preferensi atau tingkat kepentingan (W) setiap kriteria $\mathrm{W}=\left[\mathrm{W}_{1}, \mathrm{~W}_{2}, \mathrm{~W}_{3}, \ldots . \mathrm{W}_{\mathrm{j}}\right]$.

4. Membuat tabel rating kecocokan dari setiap alternatif pada setiap kriteria.

5. Membuat matriks keputusan (x) yang dibentuk dari tabel rating kecocokan dari setiap alternatif pada setiap kriteria. Nilai $\mathrm{x}$ setiap alternatif $\left(A_{i}\right)$ pada setiap kriteria $\left(C_{j}\right)$ yang sudah ditentukan, di mana, $\mathrm{i}=1,2, \ldots \mathrm{m}$ dan $\mathrm{j}=1,2, \ldots \mathrm{n}$

$$
\mathrm{X}=\left[\begin{array}{llll}
x_{11} & x_{12} & \ldots & x_{1 j} \\
\dot{\cdot} & & & \cdot \\
\dot{x_{i 1}} & x_{i 2} & \ldots & x_{i j}
\end{array}\right]
$$

6. Melakukan normalisasi matrik keputusan dengan cara menghitung nilai rating kinerja ternomalisasi $\left(r_{i j}\right)$ dari alternatif $A_{i}$ pada kriteria $\mathrm{C}_{\mathrm{j}}$

$r_{i j}$

$=\left\{\begin{array}{lr}\frac{x_{i j}}{\max _{i} x_{i j}} & \text { jika } j \text { adalah atribut keuntungan (benefit) } \\ \frac{\min _{i} x_{i j}}{x_{i j}} & \text { jika } j \text { adalah atribut biaya (cost) }\end{array}\right]$

Keterangan:

a. Kriteria keuntungan dilakukan apabila nilai memberikan keuntungan bagi pengambil keputusan. Sebaliknya, kriteria biaya dilakukan apabila menimbulkan biaya bagi pengambil keputusan.

b. Apabila berupa kriteria keuntungan maka nilai dibagi dengan nilai dari setiap kolom. Sedangkan untuk kriteria biaya, nilai dari setiap kolom dibagi dengan nilai.

7. Hasil dari nilai rating kinerja ternomalisasi $\left(\mathrm{r}_{\mathrm{ij}}\right)$ membentuk matris ternormalisasi $(\mathrm{R})$.

$$
\mathrm{R}=\left[\begin{array}{llll}
r_{11} & r_{12} & \ldots & r_{1 j} \\
\cdot & & & \cdot \\
r_{i 1} & r_{i 2} & \ldots & r_{i j}
\end{array}\right]
$$

8. Hasil akhir nilai preferensi $\left(\mathrm{V}_{\mathrm{i}}\right)$ diperoleh dari penjumlahan dan perkalian elemen baris matrik ternormalisasi (R) dengan bobot preferensi (W) yang bersesuaian elemen kolom matrik $(\mathrm{W})$.

$$
V_{i}=\sum_{j=1}^{n} W_{j} r_{i j}
$$

Keterangan :

$\mathrm{V}_{\mathrm{i}}=$ Nilai bobot preferensi dari setiap alternatif

$\mathrm{W}_{\mathrm{j}}=$ Nilai bobot dari setiap kriteria

$\mathrm{R}_{\mathrm{ij}}=$ Nilai rating kinerja ternormalisasi

Hasil perhitungan nilai $V_{i}$ yang lebih besar mengindikasikan bahwa alternatif $\mathrm{A}_{\mathrm{i}}$ merupakan alternatif terbaik.

Tahapan dalam penyelesaian metode $S A W$ dapat digambarkan dalam bagan berikut

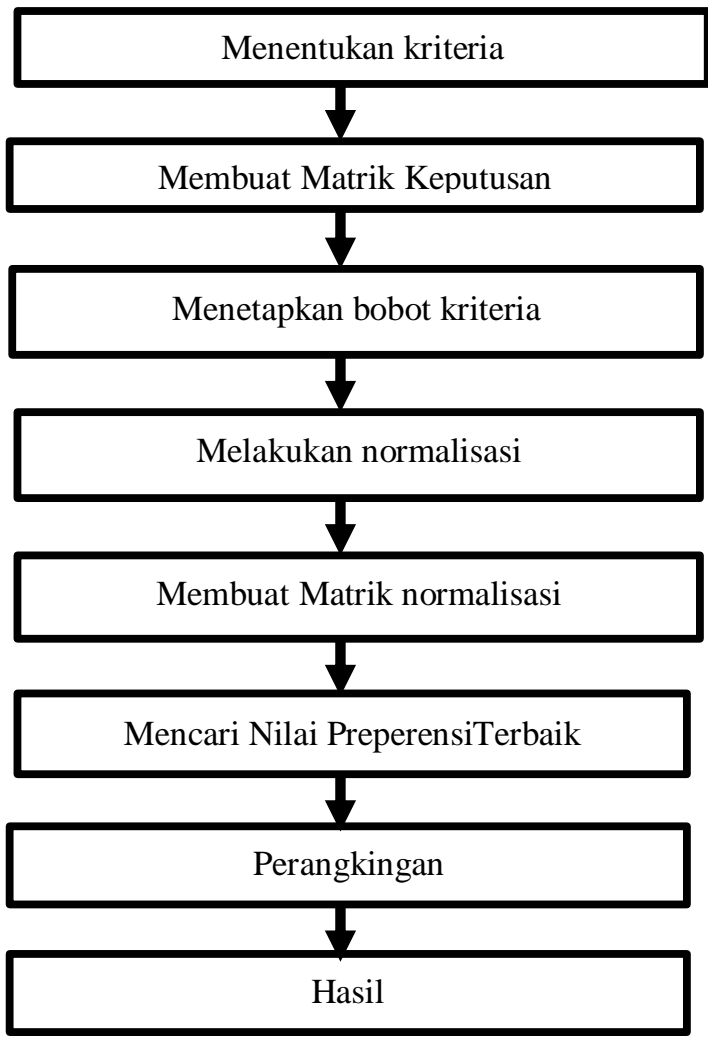

Gambar 2.1 kerangka penelitian

Berikut ini adalah tahapan pengambilan keputusan yang terbaik (Simangunsong, PBN dan Sinaga, SB, 2019):
1. Intelligence
Kecerdasan dapat didefinisikan dalam banyak pemahaman: pemahaman logika, 
IN F ORM A T I K

Jurnal Informatika, Manajemen dan Komputer, Vol. 13, No. 2, Desember 2021

eISSN : 2580-3042

pISSN : 1979-0694

kesadaran diri, pembelajaran. pengetahuan emosional, penalaran, perencanaan, kreativitas, pemikiran kritis, dan pemecahan masalah. Secara umum, ini dapat digambarkan sebagai kemampuan untuk mempersepsikan sebuah informasi, dan mempertahankannya sebagai pengetahuan yang diterapkan.

2. Design

Desain adalah rencana atau spesifikasi untuk konstruksi objek atau sistem atau untuk implementasi suatu kegiatan atau proses, atau hasil dari rencana atau spesifikasi itu dalam bentuk prototipe, produk atau proses. Kata kerja mendesain mengekspresikan proses pengembangan suatu desain.

3. Choice

Tahap ini dilakukan untuk menentukan sebuah pilihan dari berbagai aspek pencarian, evaluasi dan penyelesaian yang dibuat sesuai dengan model yang telah dirancang. Penyelesaian dengan menerapkan sebuah model adalah nilai spesifik dari alternatif yang dipilih.

4. Implementation

Implementasi diterapkan pada teknologi untuk menggambarkan interaksi unsurunsur dalam bahasa pemrograman. Penerapan dipergunakan untuk mengenal dan menggunakan elemen kode atau sumber daya pemrograman yang ditulis ke daam program.

\section{HASIL DAN PEMBAHASAN}

a. Tahapan dalam metode SAW

1. Menentukan kriteria

Kriteria dalam penjurusan siswa adalah nilai mata pelajaran. Mata pelajaran yang menjadi kriteria antara lain Bahasa Inggris, Bahasa Indonesia, IP, TIK dan Matematika. Masingmasing kriteria memiliki bobot atau tingkat kepentingan yang dapat dilihat pada tabel 1

Tabel 1

\begin{tabular}{|c|c|c|}
\hline Kriteria & $\begin{array}{c}\text { Nilai Bobot } \\
\text { Preferensi } \\
(\mathrm{W})\end{array}$ & Attribut \\
\hline $\begin{array}{c}\text { Bahasa } \\
\text { Inggris }\end{array}$ & 0,15 & Benefid \\
\hline $\begin{array}{c}\text { Bahasa } \\
\text { Indonesia }\end{array}$ & 0,10 & Benefid \\
\hline IPA & 0,20 & Benefid \\
\hline TIK & 0,25 & Benefid \\
\hline Matematika & 0,30 & Benefid \\
\hline
\end{tabular}

Sumber: SMK Al Amin

\section{Matrik Keputusan}

Berikut adalah penjabaran masingmasing kriteria yang telah dikonversikan ke bilangan fuzzy dengan nilai bobotnya

1) Kriteria Nilai Matematika $\left(C_{1}\right)$

Nilai maemaika adalah krieria dalam penenuan penjurusan siswa. Nilai siswa akan dikonversi dalam bentuk angka fuzzy berdasarkan hasil wawancara dengan wakasek dan disajikan dalam table berikut:

Tabel 2

Kriteria Nilai Matematika

\begin{tabular}{ccc}
\hline $\begin{array}{c}\text { Nilai } \\
\text { Matematika }\end{array}$ & $\begin{array}{c}\text { Bilangan } \\
\text { Fuzzy }\end{array}$ & Nilai \\
\hline $0-20$ & Rendah (R) & 2 \\
\hline $21-40$ & Cukup (C) & 3 \\
\hline $41-50$ & Tinggi (T) & 4 \\
\hline$>51$ & $\begin{array}{c}\text { Sangat } \\
\text { Tinggi (ST }\end{array}$ & 5 \\
\hline
\end{tabular}

Sumber: SMK Al Amin

2) Kriteria Nilai Bahasa Indonesia $\left(\mathrm{C}_{2}\right)$

Nilai Bahasa Indonesia adalah krieria dalam penenuan penjurusan siswa. Nilai siswa akan dikonversi dalam bentuk angka fuzzy berdasarkan hasil wawancara dengan wakasek dan disajikan dalam table berikut:

Tabel 3

Kriteria Nilai Bahasa Indonesia

\begin{tabular}{ccc}
\hline $\begin{array}{c}\text { Nilai } \\
\text { Bahasa } \\
\text { Indonesia }\end{array}$ & $\begin{array}{c}\text { Bilangan } \\
\text { Fuzzy }\end{array}$ & Nilai \\
\hline $0-20$ & Rendah (R) & 2 \\
\hline $21-40$ & Cukup (C) & 3 \\
\hline $41-50$ & Tinggi (T) & 4 \\
\hline$>51$ & $\begin{array}{c}\text { Sangat } \\
\text { Tinggi (ST }\end{array}$ & 5 \\
\hline
\end{tabular}

Sumber: SMK Al Amin

3) Kriteria Nilai Bahasa Inggris $\left(\mathrm{C}_{3}\right)$

Nilai Bahasa Inggris adalah krieria dalam penenuan penjurusan siswa. Nilai siswa akan dikonversi dalam bentuk angka fuzzy berdasarkan hasil wawancara dengan wakasek dan disajikan dalam table berikut: 
INFORM T I K

Jurnal Informatika, Manajemen dan Komputer, Vol. 13, No. 2, Desember 2021

eISSN : 2580-3042

pISSN : 1979-0694

Tabel 4

Kriteria Nilai Bahasa Inggris

\begin{tabular}{ccc}
\hline $\begin{array}{c}\text { Nilai } \\
\text { Bahasa } \\
\text { Inggris }\end{array}$ & $\begin{array}{c}\text { Bilangan } \\
\text { Fuzzy }\end{array}$ & Nilai \\
\hline $0-20$ & Rendah ( $)$ & 2 \\
\hline $21-40$ & Cukup ( & 3 \\
\hline $41-50$ & Tinggi (T) & 4 \\
\hline$>51$ & $\begin{array}{c}\text { Sangat } \\
\text { Tinggi (ST }\end{array}$ & 5 \\
\hline
\end{tabular}

Sumber : SMK Al Amin

4) Kriteria Nilai IPA $\left(\mathrm{C}_{4}\right)$

Nilai IPA adalah krieria dalam penenuan penjurusan siswa. Nilai siswa akan dikonversi dalam bentuk angka fuzzy berdasarkan hasil wawancara dengan wakasek dan disajikan dalam tabel berikut:

Tabel 5

\section{Kriteria Nilai IPA}

\begin{tabular}{ccc}
\hline $\begin{array}{c}\text { Nilai } \\
\text { IPA }\end{array}$ & $\begin{array}{c}\text { Bilangan } \\
\text { Fuzzy }\end{array}$ & Nilai \\
\hline $0-20$ & Rendah (R) & 2 \\
\hline $21-40$ & Cukup (C) & 3 \\
\hline $41-50$ & Tinggi (T) & 4 \\
\hline$>51$ & $\begin{array}{c}\text { Sangat } \\
\text { Tinggi (ST }\end{array}$ & 5 \\
\hline
\end{tabular}

Sumber: SMK Al Amin

5) Kriteria Nilai TIK $\left(\mathrm{C}_{5}\right)$

Nilai TIK adalah krieria dalam penenuan penjurusan siswa. Nilai siswa akan dikonversi dalam bentuk angka fuzzy berdasarkan hasil wawancara dengan wakasek dan disajikan dalam table berikut:

Tabel 6

Kriteria Nilai TIK

\begin{tabular}{ccc}
\hline $\begin{array}{c}\text { Nilai } \\
\text { IPA }\end{array}$ & $\begin{array}{c}\text { Bilangan } \\
\text { Fuzzy }\end{array}$ & Nilai \\
\hline $0-20$ & Rendah (R) & 2 \\
\hline $21-40$ & Cukup (C) & 3 \\
\hline $41-50$ & Tinggi (T) & 4 \\
\hline$>51$ & $\begin{array}{c}\text { Sangat } \\
\text { Tinggi (ST }\end{array}$ & 5 \\
\hline
\end{tabular}

Sumber: SMK Al Amin

\section{Menentukan bobot kriteria}

Langkah selajutkan menentukan masing-masing kriteria tersebut untuk ditentukan rating kecocokan setiap alternatif pada setiap kriteria, yaitu lihat pada tabel 7

Tabel 7

Tingkat Kepentingan Kriteria

\begin{tabular}{|c|c|c|c|c|}
\hline No & \multicolumn{2}{|r|}{ Kriteria $\left(C_{j}\right)$} & \multirow{2}{*}{$\begin{array}{l}\text { Bobot } \\
30 \% \\
\end{array}$} & \multirow{2}{*}{$\begin{array}{l}\text { Nilai } \\
\text { Bobot } \\
(\mathrm{W}) \\
0,30\end{array}$} \\
\hline 1 & $\mathrm{C}_{1}$ & Matematika & & \\
\hline 2 & $\mathrm{C}_{2}$ & $\begin{array}{l}\text { Bahasa } \\
\text { Inggris }\end{array}$ & $15 \%$ & 0,15 \\
\hline 3 & $\mathrm{C}_{3}$ & $\begin{array}{l}\text { Bahasa } \\
\text { Indonesia }\end{array}$ & $10 \%$ & 0,10 \\
\hline 4 & $\mathrm{C}_{4}$ & IPA & $20 \%$ & 0,20 \\
\hline 5 & $\mathrm{C}_{5}$ & TIK & $25 \%$ & 0,25 \\
\hline \multicolumn{4}{|c|}{ Bobot } & 1 \\
\hline
\end{tabular}

Sumber: SMK Al Amin

Dari tabel di atas, dapat diartikan matematika adalah kriteria utama yang memiliki bobot paling besar disbanding nilai lain dan bobot terendah adalah nilai Bahasa Indonesia.

\section{Melakukan normalisasi}

Tabel 8

Data Alternatif

\begin{tabular}{|c|l|}
\hline Kode & \multicolumn{1}{|c|}{ Keterangan } \\
\hline A1 & Teknik Komputer dan Jaringan (TKJ) \\
\hline A2 & Akuntasi Keuangan dan Lembaga (AKL) \\
\hline A3 & $\begin{array}{l}\text { Otomatisasi Tata Kelola dan Perkantoran } \\
\text { (OTKP) }\end{array}$ \\
\hline A4 & Bisnis Daringa dan Pemasaran (BDP) \\
\hline
\end{tabular}

Sumber: SMK Al Amin

Tabel di atas menggambarkan data alternatif jurusan yang bisa dipilih oleh siswa. Diinisialkan dengan A1 untuk KJ, A2 untuk AKL, A3 untuk OTKP dan A4 untuk BDP.

Tabel 9

Data table referensi jurusan

\begin{tabular}{|c|c|c|}
\hline No & $\begin{array}{c}\text { Rata-rata } \\
\text { Jurusan }\end{array}$ & Nama Jurusan \\
\hline 1 & $0.91-1.00$ & $\begin{array}{c}\text { Teknik Komputer dan } \\
\text { Jaringan (TKJ) }\end{array}$ \\
\hline 2 & $0.81-0.90$ & $\begin{array}{c}\text { Akuntasi Keuangan } \\
\text { dan Lembaga (AKL) }\end{array}$ \\
\hline 3 & $0.71-0.80$ & $\begin{array}{c}\text { Otomatisasi Tata } \\
\text { Kelola dan Perkantoran } \\
\text { (OTKP) }\end{array}$ \\
\hline 4 & $0.00-0.70$ & $\begin{array}{c}\text { Bisnis Daringa dan } \\
\text { Pemasaran (BDP) }\end{array}$ \\
\hline
\end{tabular}

Sumber: SMK Al Amin 
I N F O R M A T I K A

Jurnal Informatika, Manajemen dan Komputer, Vol. 13, No. 2, Desember 2021

eISSN : 2580-3042

pISSN : 1979-0694

Tabel 9 menggambarkan referensi jurusan siswa. Nilai yang diperoleh dari perhitungan masing-masing alternatif memiliki makna, pada jurusan apa dia akan dierima. Jika rentang nilai antara 0.91 sampai 1 maka akan diterima di $\mathrm{KJ}$, jika nilai ada pada rentang 0.81 sampai 0.9 akan diterima di AKL, jika nilai berada di rentang antara 0.71 sampai 0.8 akan diterima di OTKP dan jika nilai yang diperoleh siswa kurang dari 0.71 maka akan diterima di BDP.

Berikut data alternatif siswa yang akan dilakukan penilaian penjurusan dengan masingmasing nilai yang dimiliki oleh siswa. Dalam penelitian ini menggunakan sepuluh data sebagai sampel yang akan dilakukan perhitungan SAW.

Tabel 10

Sample Data Hasil Ujian

\begin{tabular}{|c|c|c|c|c|c|c|}
\hline \multirow{2}{*}{ No } & \multirow{2}{*}{ Nama Siswa } & \multicolumn{5}{|c|}{ Kriteria } \\
\hline & & $\mathrm{C}_{1}$ & $\mathrm{C}_{2}$ & $\mathrm{C}_{3}$ & $\mathrm{C}_{4}$ & $\mathrm{C}_{5}$ \\
\hline 1. & $\begin{array}{l}\text { SITI } \\
\text { NURHALIMAH }\end{array}$ & 50 & 50 & 55 & 60 & 50 \\
\hline 2. & $\begin{array}{l}\text { DZAKY } \\
\text { AKBAR } \\
\text { ANHARI }\end{array}$ & 85 & 55 & 63 & 70 & 78 \\
\hline 3. & $\begin{array}{l}\text { WISNU AJI } \\
\text { SEPTIAWAN }\end{array}$ & 58 & 46 & 49 & 52 & 55 \\
\hline 4. & $\begin{array}{l}\text { NABILATUL } \\
\text { IKHLASIYAH }\end{array}$ & 82 & 54 & 61 & 68 & 75 \\
\hline 5. & $\begin{array}{l}\text { KARINA } \\
\text { AULIA AYUBI }\end{array}$ & 85 & 55 & 63 & 70 & 78 \\
\hline 6. & $\begin{array}{l}\text { RIRIN } \\
\text { KHAERUNISSA }\end{array}$ & 73 & 51 & 57 & 62 & 68 \\
\hline 7. & $\begin{array}{l}\text { DIMAS } \\
\text { BUDIMAN }\end{array}$ & 79 & 53 & 60 & 66 & 73 \\
\hline 8. & $\begin{array}{l}\text { NIHA } \\
\text { SARASWATI }\end{array}$ & 73 & 51 & 57 & 62 & 68 \\
\hline 9. & $\begin{array}{l}\text { PEBRIANTI } \\
\text { TATI ADZUHRI }\end{array}$ & 100 & 60 & 70 & 80 & 90 \\
\hline 10. & $\begin{array}{l}\text { GINA } \\
\text { MUTMAINAH }\end{array}$ & 100 & 60 & 70 & 80 & 95 \\
\hline
\end{tabular}

Sumber: SMK Al Amin

Matrik keputusan

$X=\left[\begin{array}{ccccc}50 & 50 & 55 & 60 & 50 \\ 85 & 55 & 63 & 70 & 78 \\ 58 & 46 & 49 & 52 & 55 \\ 82 & 54 & 61 & 68 & 75 \\ 85 & 55 & 63 & 70 & 78 \\ 73 & 51 & 57 & 62 & 68 \\ 79 & 53 & 60 & 66 & 73 \\ 73 & 51 & 57 & 62 & 68 \\ 100 & 60 & 70 & 80 & 90 \\ 100 & 60 & 70 & 80 & 95\end{array}\right]$

\section{Mencari nilai preperensi terbaik}

$r_{11}$

$=\frac{50}{\max \{50 ; 85 ; 58 ; 82 ; 85 ; 73 ; 79 ; 73 ; 100 ; 100\}}$

$=\frac{50}{100}=0,50$

$r_{12}$

$=\frac{50}{\max \{50 ; 55 ; 46 ; 54 ; 55 ; 51 ; 53 ; 51 ; 60 ; 60\}}$

$=\frac{50}{60}=0,83$

$r_{13}$

$=\frac{55}{\max \{55 ; 63 ; 49 ; 61 ; 63 ; 57 ; 60 ; 57 ; 70 ; 70\}}$

$=\frac{55}{70}=0,79$

$r_{14}$

$=\frac{60}{\max \{60 ; 70 ; 52 ; 68 ; 70 ; 62 ; 66 ; 62 ; 80 ; 80\}}$

$=\frac{60}{80}=0,75$

$r_{15}$

$=\frac{50}{\max \{50 ; 78 ; 55 ; 75 ; 78 ; 68 ; 73 ; 68 ; 90 ; 95\}}$

$=\frac{50}{95}=0,53$

$r 21$

$=\frac{85}{\max \{50 ; 85 ; 58 ; 82 ; 85 ; 73 ; 79 ; 73 ; 100 ; 100\}}$

$=\frac{85}{100}=0,85$

$r_{22}$

$=\frac{55}{\max \{50 ; 55 ; 46 ; 54 ; 55 ; 51 ; 53 ; 51 ; 60 ; 60\}}$

$=\frac{55}{60}=0,92$

$r_{23}$

$=\frac{63}{\max \{55 ; 63 ; 49 ; 61 ; 63 ; 57 ; 60 ; 57 ; 70 ; 70\}}$

$=\frac{63}{70}=0,90$

$=\frac{r_{24}}{\max \{60 ; 70 ; 52 ; 68 ; 70 ; 62 ; 66 ; 62 ; 80 ; 80\}}$

$=\frac{70}{80}=0,86$ 
INFORM T I K A

Jurnal Informatika, Manajemen dan Komputer, Vol. 13, No. 2, Desember 2021

eISSN : 2580-3042

pISSN : 1979-0694

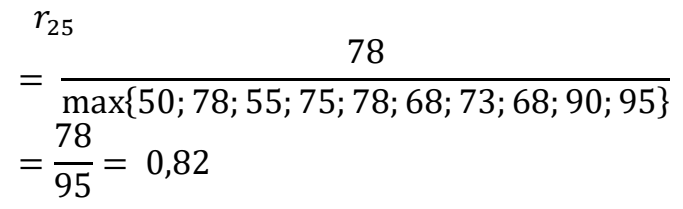

$r 31$

$=\frac{58}{\max \{50 ; 85 ; 58 ; 82 ; 85 ; 73 ; 79 ; 73 ; 100 ; 100\}}$ $=\frac{58}{100}=0,58$

$r_{32}$

$=\frac{46}{\max \{50 ; 55 ; 46 ; 54 ; 55 ; 51 ; 53 ; 51 ; 60 ; 60\}}$

$=\frac{46}{60}=0,76$

$r_{33}$

$=\frac{49}{\max \{55 ; 63 ; 49 ; 61 ; 63 ; 57 ; 60 ; 57 ; 70 ; 70\}}$

$=\frac{49}{70}=0,70$

$r_{34}$

$=\frac{52}{\max \{60 ; 70 ; 52 ; 68 ; 70 ; 6}$

$=\frac{70}{80}=0,65$

$r_{35}$

$=\frac{55}{\max \{50 ; 78 ; 55 ; 75 ; 78 ; 68 ; 73 ; 68 ; 90 ; 95\}}$

$=\frac{55}{95}=0,58$

$r 41$

$=\frac{82}{\max \{50 ; 85 ; 58 ; 82 ; 85 ; 73 ; 79 ; 73 ; 100 ; 100\}}$ $=\frac{82}{100}=0,82$

$$
\begin{aligned}
& r_{42} \\
= & \frac{54}{\max \{50 ; 55 ; 46 ; 54 ; 55 ; 51 ; 53 ; 51 ; 60 ; 60\}} \\
= & \frac{54}{60}=0,90 \\
& r_{43} \\
= & \frac{61}{\max \{55 ; 63 ; 49 ; 61 ; 63 ; 57 ; 60 ; 57 ; 70 ; 70\}} \\
= & \frac{61}{70}=0,87
\end{aligned}
$$

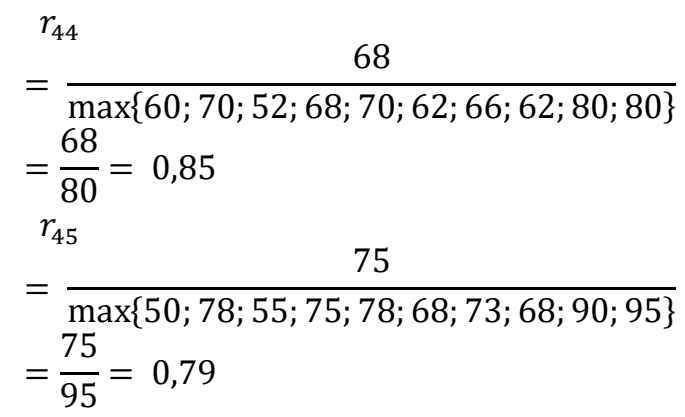

$r 51$

$=\frac{85}{\max \{50 ; 85 ; 58 ; 82 ; 85 ; 73 ; 79 ; 73 ; 100 ; 100\}}$ $=\frac{85}{100}=0,85$

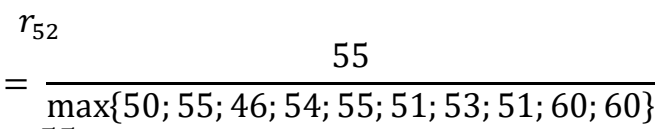
$=\frac{55}{60}=0,92$

$r_{53}$

$=\frac{63}{\max \{55 ; 63 ; 49 ; 61 ; 63 ; 57 ; 60 ; 57 ; 70 ; 70\}}$ $=\frac{63}{70}=0,90$

$r_{54}$

$=\frac{70}{\max \{60 ; 70 ; 52 ; 68 ; 70 ; 62 ; 66 ; 62 ; 80 ; 80\}}$ $=\frac{70}{80}=0,86$

$r_{55}$

$=\frac{78}{\max \{50 ; 78 ; 55 ; 75 ; 78 ; 68 ; 73 ; 68 ; 90 ; 95\}}$ $=\frac{78}{95}=0,82$

$r 61$

$=\frac{73}{\max \{50 ; 85 ; 58 ; 82 ; 85 ; 73 ; 79 ; 73 ; 100 ; 100\}}$ $=\frac{73}{100}=0,73$

$$
\begin{aligned}
& r_{62} \\
& =\frac{51}{\max \{50 ; 55 ; 46 ; 54 ; 55 ; 51 ; 53 ; 51 ; 60 ; 60\}} \\
& =\frac{51}{60}=0,85
\end{aligned}
$$


INFORM T I K A

Jurnal Informatika, Manajemen dan Komputer, Vol. 13, No. 2, Desember 2021

eISSN : 2580-3042

pISSN : 1979-0694

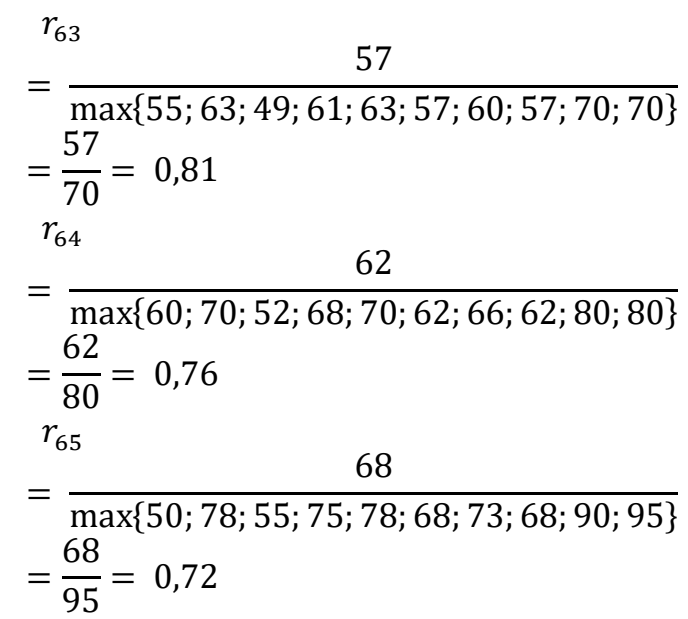

$r 71$

$=\frac{79}{\max \{50 ; 85 ; 58 ; 82 ; 85 ; 73 ; 79 ; 73 ; 100 ; 100\}}$ $=\frac{79}{100}=0,79$
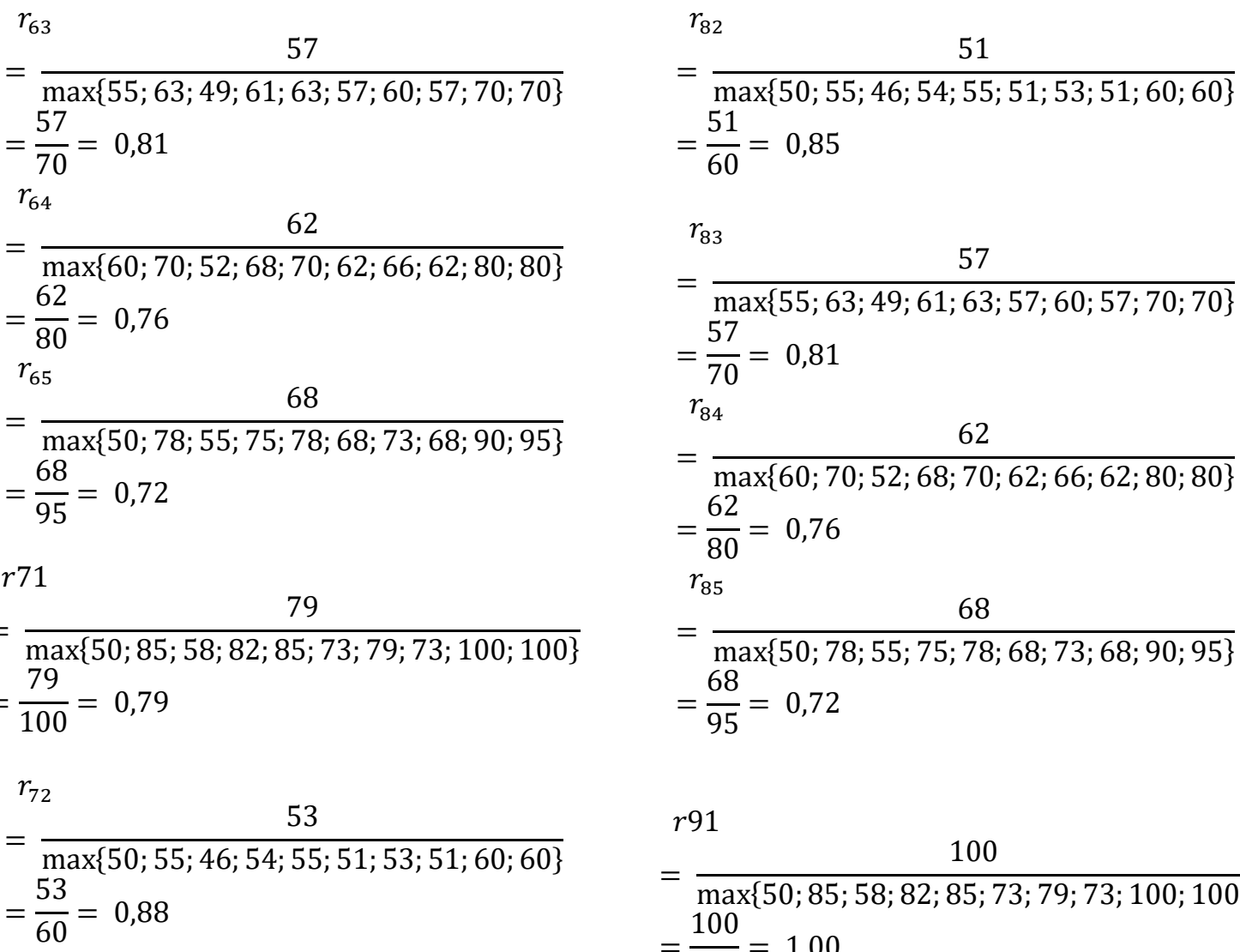

$r_{73}$

$=\frac{60}{\max \{55 ; 63 ; 49 ; 61 ; 63 ; 57 ; 60 ; 57 ; 70 ; 70\}}$ $=\frac{60}{70}=0,86$

$r_{74}$

66

$=\frac{66}{\max \{60 ; 70 ; 52 ; 68 ; 70 ; 62 ; 66 ; 62 ; 80 ; 80\}}$

$=\frac{66}{80}=0,83$

$r_{75}$

$=\frac{73}{\max \{50 ; 78 ; 55 ; 75 ; 78 ; 68 ; 73 ; 68 ; 90 ; 95\}}$

$=\frac{73}{95}=0,77$

$$
\begin{aligned}
& r 91 \\
&= \frac{100}{\max \{50 ; 85 ; 58 ; 82 ; 85 ; 73 ; 79 ; 73 ; 100 ; 100\}} \\
&= \frac{100}{100}=1,00 \\
& r_{92} \\
&= \frac{60}{\max \{50 ; 55 ; 46 ; 54 ; 55 ; 51 ; 53 ; 51 ; 60 ; 60\}} \\
&= \frac{60}{60}=1,00 \\
& r_{93} \\
&= \frac{70}{\max \{55 ; 63 ; 49 ; 61 ; 63 ; 57 ; 60 ; 57 ; 70 ; 70\}} \\
&= \frac{70}{70}=1,00 \\
& r_{94} \\
&= \frac{80}{\max \{60 ; 70 ; 52 ; 68 ; 70 ; 62 ; 66 ; 62 ; 80 ; 80\}} \\
&= \frac{80}{80}=1,00 \\
& r_{95} \\
&= \frac{90}{\max \{50 ; 78 ; 55 ; 75 ; 78 ; 68 ; 73 ; 68 ; 90 ; 95\}} \\
&= \frac{90}{95}=0,98 \quad 96
\end{aligned}
$$


I N F O R M A T I K A

Jurnal Informatika, Manajemen dan Komputer, Vol. 13, No. 2, Desember 2021 eISSN : 2580-3042

pISSN : 1979-0694

$$
\begin{array}{rl}
r & 10-1 \\
= & \frac{100}{\max \{50 ; 85 ; 58 ; 82 ; 85 ; 73 ; 79 ; 73 ; 100 ; 100\}} \\
= & \frac{100}{100}=1,00 \\
& r_{10-2} \\
= & \frac{60}{\max \{50 ; 55 ; 46 ; 54 ; 55 ; 51 ; 53 ; 51 ; 60 ; 60\}} \\
= & \frac{60}{60}=1,00 \\
& r_{10-3} \\
= & \frac{\max \{55 ; 63 ; 49 ; 61 ; 63 ; 57 ; 60 ; 57 ; 70 ; 70\}}{70}=1,00 \\
= & \frac{70}{70}=1,80 \\
& r_{10-4} \\
= & \frac{80}{\max \{60 ; 70 ; 52 ; 68 ; 70 ; 62 ; 66 ; 62 ; 80 ; 80\}} \\
= & \frac{80}{80}=1,00 \\
& r_{10-5} \\
= & \frac{95}{\max \{50 ; 78 ; 55 ; 75 ; 78 ; 68 ; 73 ; 68 ; 90 ; 95\}}=1,00 \\
95 & 95
\end{array}
$$

$\mathrm{V} 1=\{(0,0)(0,50)+(0,15)(0,833)+(0,10)(0,785)$ $+(0,20)(0,75)+(0,25)(0,526)\}=0,635$

$\mathrm{V} 2=\{(0,30)(0,85)+(0,15)(0,916)+(0,10)(0,9)$ $+(0,20)(0,875)+(0,25)(0,821)\}=0,862$

$\mathrm{V} 3=\{(0,30)(0,58)+(0,15)(0,766)+(0,10)(0,7)$ $+(0,20)(0,65)+(0,25)(0,578)\}=0,630$

$\mathrm{V} 4=\{(0,30)(0,82)+(0,15)(0,9)+(0,10)(0,871)$ $+(0,20)(0,85)+(0,25)(0,789)\}=0,835$

$\mathrm{V} 5=\{(0,30)(0,85)+(0,15)(0,916)+(0,10)(0,9)$

$+(0,20)(0,875)+(0,25)(0,821)\}=0,862$

V6 $=\{(0,30)(0,73)+(0,15)(0,85)+(0,10)(0,81)$

$+(0,20)(0,775)+(0,25)(0,715)\}=0,76$

$\mathrm{V} 7=\{(0,30)(0,79)+(0,15)(0,88)+(0,10)(0,86)$

$+(0,20)(0,83)+(0,25)(0,77)\}=0,812$

$\mathrm{V} 8=\{(0,30)(0,73)+(0,15)(0,85)+(0,10)(0,81)$

$+(0,20)(0,775)+(0,25)(0,72)\}=0,76$

$\mathrm{V} 9=\{(0,30)(1)+(0,15)(1)+(0,10)(1)+$

$(0,20)(1)+(0,25)(0,947)\}=0,986$

$\mathrm{V} 10=\{(0,30)(1)+(0,15)(1)+(0,10)(1)+$ $(0,20)(1)+(0,25)(1)\}=1$

\section{Perangkingan}

Data sampel yang sudaah dilakukan perhitungan dengan metode SAW hasilnya dilakukan perangkingan, diurutkan dari hasil tertinggi, hasilnya dapat disajikan dalam tabel berikut:

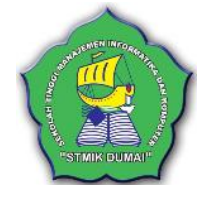

\begin{tabular}{|c|c|l|c|}
\multicolumn{5}{|c}{ Tabel 11 Perangkingan } \\
\hline Rangking & $\mathrm{V}_{\mathrm{i}}$ & \multicolumn{1}{|c|}{ Nama } & Nilai \\
\hline 1 & $\mathrm{~A}_{10}$ & $\begin{array}{l}\text { GINA } \\
\text { MUTMAINAH }\end{array}$ & 1 \\
\hline 2 & $\mathrm{~A}_{9}$ & $\begin{array}{l}\text { PEBRIANTI } \\
\text { TATI ADZUHRI }\end{array}$ & 0,986 \\
\hline 3 & $\mathrm{~A}_{2}$ & $\begin{array}{l}\text { DZAKY } \\
\text { AKBAR } \\
\text { ANHARI }\end{array}$ & 0,862 \\
\hline 4 & $\mathrm{~A}_{5}$ & $\begin{array}{l}\text { KARINA } \\
\text { AULIA AYUBI }\end{array}$ & 0,862 \\
\hline 5 & $\mathrm{~A}_{4}$ & $\begin{array}{l}\text { NABILATUL } \\
\text { IKHLASIYAH }\end{array}$ & 0,835 \\
\hline 6 & $\mathrm{~A}_{7}$ & $\begin{array}{l}\text { DIMAS } \\
\text { BUDIMAN }\end{array}$ & 0,812 \\
\hline 7 & $\mathrm{~A}_{6}$ & $\begin{array}{l}\text { RIRIN } \\
\text { KHAERUNISSA }\end{array}$ & 0,76 \\
\hline 8 & $\mathrm{~A}_{8}$ & $\begin{array}{l}\text { NIHA } \\
\text { SARASWATI }\end{array}$ \\
\hline 9 & $\mathrm{~A}_{1}$ & $\begin{array}{l}\text { SITI } \\
\text { NURHALIMAH }\end{array}$ & 0,635 \\
\hline 10 & $\mathrm{~A}_{3}$ & $\begin{array}{l}\text { WISNU AJI } \\
\text { SEPTIAWAN }\end{array}$ & 0,63 \\
\hline
\end{tabular}

Sumber: Hasil Pengolahan Data Dengan SAW

\section{Hasil}

Hasil perangkingan dihubungkan dengan table referensi (table 3.9) untuk dapat menentukan hasil penempatan jurusan siswa. Data sampel yang diolah menghasilkan referensi penentuan jurusan siswa terdapat dalam tabel 3.13

Tabel 12 Hasil

\begin{tabular}{|c|c|c|c|c|}
\hline Rangking & $\mathrm{V}_{\mathrm{i}}$ & \multicolumn{1}{|c|}{ Nama } & Nilai & $\begin{array}{c}\text { Jurusa } \\
\mathrm{n}\end{array}$ \\
\hline 1 & $\mathrm{~A}_{10}$ & $\begin{array}{l}\text { GINA } \\
\text { MUTMAIN } \\
\text { AH }\end{array}$ & 1 & TKJ \\
\hline 2 & $\mathrm{~A}_{9}$ & $\begin{array}{l}\text { PEBRIANT } \\
\text { I TATI } \\
\text { ADZUHRI }\end{array}$ & 0,986 & TKJ \\
\hline 3 & $\mathrm{~A}_{2}$ & $\begin{array}{l}\text { DZAKY } \\
\text { AKBAR } \\
\text { ANHARI }\end{array}$ & 0,862 & AKL \\
\hline 4 & $\mathrm{~A}_{5}$ & $\begin{array}{l}\text { KARINA } \\
\text { AULIA } \\
\text { AYUBI }\end{array}$ & 0,862 & AKL \\
\hline 5 & $\mathrm{~A}_{4}$ & $\begin{array}{l}\text { NABILAT } \\
\text { UL } \\
\text { IKHLASIY } \\
\text { AH }\end{array}$ & 0,835 & AKL \\
\hline
\end{tabular}


I N F ORM A T I K

Jurnal Informatika, Manajemen dan Komputer, Vol. 13, No. 2, Desember 2021

eISSN : 2580-3042

pISSN : 1979-0694

\begin{tabular}{|c|c|l|c|c|}
\hline 6 & $\mathrm{~A}_{7}$ & $\begin{array}{l}\text { DIMAS } \\
\text { BUDIMAN }\end{array}$ & 0,812 & AKL \\
\hline 7 & $\mathrm{~A}_{6}$ & $\begin{array}{l}\text { RIRIN } \\
\text { KHAERUN } \\
\text { ISSA }\end{array}$ & 0,76 & OTKP \\
\hline 8 & $\mathrm{~A}_{8}$ & $\begin{array}{l}\text { NIHA } \\
\text { SARASWA } \\
\text { TI }\end{array}$ & 0,76 & OTKP \\
\hline 9 & $\mathrm{~A}_{1}$ & $\begin{array}{l}\text { SITI } \\
\text { NURHALI } \\
\text { MAH }\end{array}$ & 0,635 & BDP \\
\hline 10 & $\mathrm{~A}_{3}$ & $\begin{array}{l}\text { WISNU AJI } \\
\text { SEPTIAW } \\
\text { AN }\end{array}$ & 0,63 & BDP \\
\hline
\end{tabular}

\section{b. Implementasi Aplikasi}

Hasil dari implementasi aplikasi dalam pengolahan data menggunakan metode SAW dapat secara garis besar digambarkan dalam tiga tahapan berikut:

\section{a. Data Siswa}

Data siswa sebagai alternatif yang akan diolah datanya, dimasukkan ke dalam aplikasi.

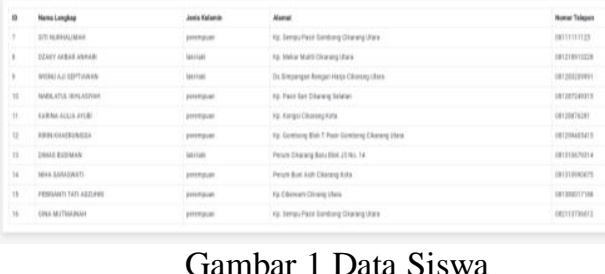

b. Proses

Gambar 1 Data Siswa

Data siswa beserta nilainya yang sudah diinput, kemudian dilakukan proses SAW yang menghasilkan referensi hasilnya terlihat dalam gambar 2 .

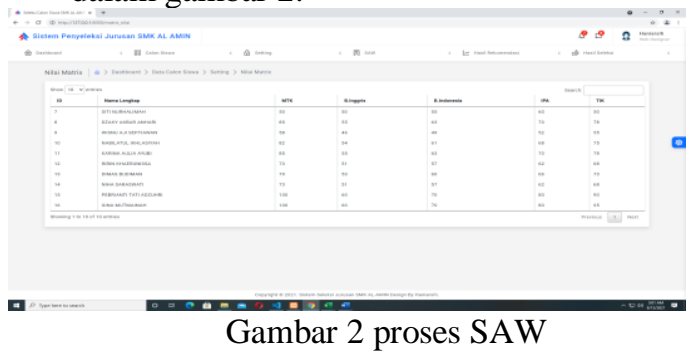

c. Preferensi

Proses selanjutnya adalah preferensi adalah proses perhitungan nilai siswa terdapat pada gambar 3.3.

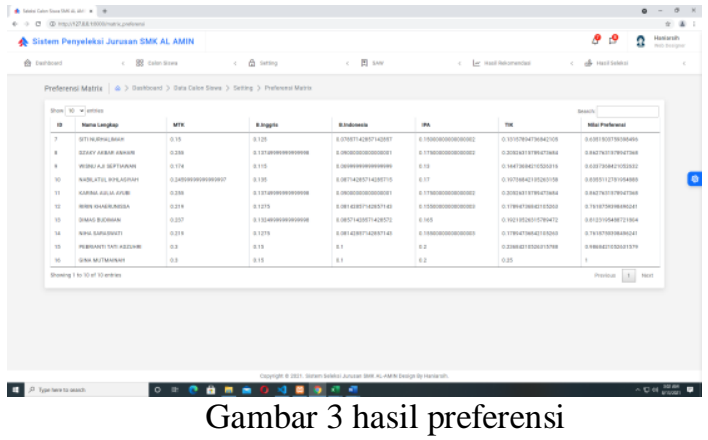

d. Rekomendasi Jurusan

Hasil terakhir dari semua proses ini adalah rekomendasi penentuan jurusan siswa. Hasil rekomendasi dari aplikasi terlihat dalam gambar 3.4.0000000000000000

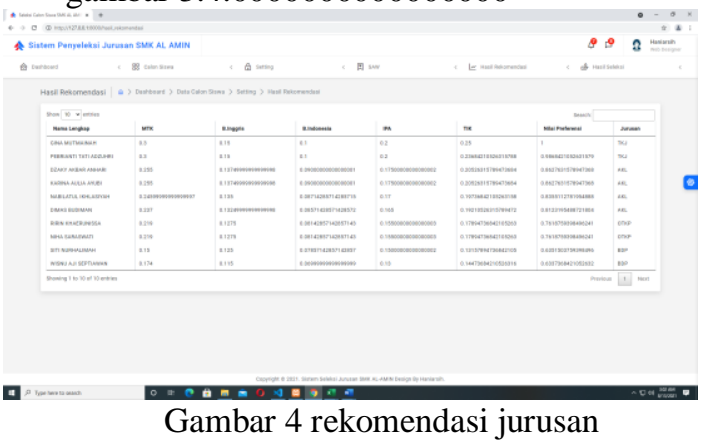

\section{KESIMPULAN}

Berdasarkan hasil penelitian yang telah dilakukan maka dapat disimpulkan bahwa Metode $S A W$ dapat diterapkan dalam menentukan jurusan siswa. serta Metode $S A W$ yang dimplementasikan dalam sistem berbasis Web memudahkan proses penentuan jurusan bagi siswa dan dapat dilakukan tidak harus di sekolah.

\section{REFERENSI}

Asnawati, Indra Kanedi. 2012. Sistem Pendukung Keputusan Kenaikan Pangkat Karyawan Perseroan Terbatas Pelayaran Kumafa Lagun Marina Bengkulu. ISSN: 1858-2680. Bengkulu: Jurnal Media Infotama Vol.8, No. 1 Februari 2012: 118137

Frieyadie. (2016). Penerapan Metode Simple Additive Weight (SAW). Pilar Nusa Mandiri Vol.XII, No. 1 Maret 2016, 38-39.

Handayani DN, Hakim FN, Solechan A, 2014. Sistem Pendukung Keputusan Untuk Pemilihan Jurusan Menggunakan Fuzzy 
IN F O RM A I I A

Jurnal Informatika, Manajemen dan Komputer, Vol. 13, No. 2, Desember 2021

elSSN : 2580-3042

pISSN : 1979-0694

Multiple Atribute Decision Making

Dengan Metode Simple Additive

Weighting Studi Kasus Pada Sma Islam

Sultan Agung 1 Semarang. Jogyakarta:

JURNAL TRANSFORMATIKA, Volume

11, No.2, Januari $2014: 69-78$

Kusrini. 2007. Konsep dan Aplikasi Sistem Pendukung Keputusan. Yogyakarta: Andy Offset.

Munthe, Hotmaria Ginting. 2013. Sistem Pendukung Keputusan Penentuan Prioritas Usulan Sertifikasi Guru Dengan Metode Simple Additive Weighting. ISSN: 23019425. Medan: Pelita Informatika Budi Darma Vol IV, No. 2 Agustus 2013: 52-58

Rusdiyansah, 2017.Analisis Keputusan

Menentukan Jurusan Pada Sekolah Menengah Kejuruan Dengan Metode Simple Additive Weighting. ISSN 19782136. Jakarta: Jurnal Techno Nusa Mandiri Vol. XIV, No. 1 Maret 2017: 50 58

Simangunsong, PBN dan Sinaga, SB. 2019. Sistem Pendukung Keputusan Pemilihan Dosen Berprestasi dengan Metode Electre Berbasis Web. Kita Menulis 